\title{
Re-conceptualising Approaches to Meeting the Health Needs of Homeless People
}

\author{
ISOBEL ANDERSON* and SIRI YTREHUS** \\ * School of Applied Social Science, University of Stirling, Stirling FK9 4LA, United Kingdom \\ email: Isobel.anderson@stir.ac.uk \\ ** Diakonhjemmet University College, Institute of Nursing and Health, Oslo, Norway \\ email: siri.ytrehus@diakonhjemmet.no
}

\begin{abstract}
The experience of homelessness not only affects physical health, but can also constrain access to required health care. In a number of European countries, national strategies to tackle homelessness have sought to deliver integrated solutions across housing, health and other social policy areas. This article examines approaches to meeting the health care needs of homeless people in relation to such strategies, drawing upon recent research in Norway and Scotland. The article presents a comparative analysis of approaches to service provision in relation to welfare models and the concepts of universal and specialist provision. The analysis suggests a cross-national shift in the conceptualisation of appropriate responses to the health care needs of those who experience homelessness. The provision of some specialist health services, while reflecting a selective model of welfare, need not be solely interpreted as conflicting with a more universal model of ensuring access to mainstream services. Rather, the challenge is to recognise the need for a process approach which supports an effective transition from the (sometimes necessary) use of specialist services for this group, towards (the ideal of) full integration into mainstream health care.
\end{abstract}

\section{Introduction}

The post-200o period has seen increasing social policy attention directed towards homelessness across and beyond the European Union (EU). Many countries, for example Australia, France, Ireland, the Netherlands, Portugal, all four Nordic countries and the United Kingdom introduced national strategies or legislative frameworks which incorporated measurable targets to substantially reduce, or even eradicate homelessness within set timescales. International research has also indicated a consensus that homelessness is a multidimensional problem requiring comprehensive responses to meet the health and social support needs of homeless people, alongside the provision of adequate, affordable accommodation (Anderson et al., 2006; Busch-Geertsema et al., 2010).

The health characteristics of homeless people have long been a focus for medical research but it is also important to examine health and homelessness from a social policy perspective as part of the evolution of comprehensive, 
integrated approaches to relieving homelessness. For example, a major review of homelessness in Scotland recognised that the health needs of the homeless population were not well met by current health services (Homelessness Task Force, 2002). This paper seeks to contribute to the scholarly literature on health and homelessness through a comparison of responses to homelessness in Norway and Scotland which re-examines conceptualisations of welfare policy approaches to meeting the health care needs of homeless people.

The principles and objectives of universalist social service and selective social service have long been central to discussions of the development of the welfare state (Alcock et al., 2001:116-17). Usually we think of universal welfare as delivering services that are available and accessible to all without involving lack of dignity or self-respect, or stigma. The service should neither be only for those who can afford it, nor only for a small group (devaluing and stigmatising the users). Services developed according to the universalist principle can also have a preventive function because they are delivered through socially approved channels, and this is an important premise for their use by all of the population (Alcock et al., 2001: 117). On the other hand, selective services are those services which are delivered for specific groups such as homeless or poor people, and are associated with a residual, rather than a classical, welfare state model. Along with social security, education and the personal social services, health care and housing were originally treated as two of the welfare state's central services (Alcock et al, 2001; Kemeny, 2001), albeit that state housing policy has incorporated intervention in the private rented and owner-occupied sectors as well as direct provision of public rented housing. While we acknowledge the diversity of health care systems across welfare states, as well as the fact that their nature changes over time, for this paper, in relation to Norway and Scotland, we use the terms 'universal' and 'mainstream' as being broadly synonymous with services available and accessible to the whole population; and the terms 'selective' and 'specialist' to refer to services which are provided in response to the exclusion of some groups from services which should be available for all, but where in practice they are not.

The question arises then as to how the difference between mainstream and specialist service provision can be accurately characterised? And perhaps more importantly, how do we know which structures work best for homeless people? Moreover, service provision is likely to evolve over time. Richard Titmuss (1968) himself pointed out that there are many forms of universalism and selective service. Titmuss did not altogether reject selective services, but warned against simplification of the distinction between universalist and selective social services. The challenge - according to Titmuss - was to find out what particular infrastructure of universalist services was needed in order to provide a framework of values and opportunity bases within and around which socially acceptable selective services could be developed, aiming to discriminate positively those whose needs are greatest, with the minimal risk of stigma (Titmuss, 1968). 
Drawing on the concepts of universalism and selectivity in welfare provision, this paper aims to systematically analyse and compare two states' health care systems and homelessness strategies in order to arrive at a better understanding of the changing approaches which have underpinned policy developments. Norway and Scotland are examples of countries with well-developed nationallevel responses to homelessness, which have emerged in different welfare systems. Norway remains a universalist welfare state under Esping-Andersen's (1990) classification. Scotland, as part of the UK, is characterised as a liberal welfare regime, though its earlier more social democratic roots have bequeathed a universal national health service. Health and housing are two of the significant social policy areas which have been fully devolved to the Scottish Parliament since 1999, making Scotland a distinct case study (rather than merely representing a region of the UK). As of 2011, Scotland was not subject to the same proposals for NHS reform as England (Department of Health, 2011).

This paper argues that although the ideal of universal health care for homeless people may be shared by two countries, differences may be identified in terms of service provision and different challenges may emerge in meeting that ideal. More specifically, we want to address the following questions:

1. How can we best conceptualise the strategies to meet the health needs of homeless people in Norway and Scotland?

2. What are the implications from this analysis for the wider debate on how to best meet the health care needs of homeless people?

Our analytical approach involved a review of relevant literature followed by a detailed analysis of relevant policy documents and available evidence on policy implementation and outcomes in the two countries. The comparative analysis was conducted during a series of short exchange visits between the two countries, as well as discussions at Nordic and European conferences. This approach was necessary in order to analyse and compare how the two nations approach health care provision for homeless people, prior to designing a more evaluative study for implementation. While we have endeavoured to produce a balanced comparison, it should be noted that Scotland has paid more sustained attention to homelessness over a longer period than Norway. The Scottish local and central state measures and initiatives have been more diverse and extensive, and Scotland also has a more extensive research evidence base on homelessness, including collection of routine statistics by housing authorities.

The next section compares the national homelessness frameworks and the mechanisms to address the health care needs of homeless people in Norway and Scotland. We then further develop our two-country comparative analysis in the context of the wider international research evidence on health and homelessness and the debate around universal (mainstream) and selective (specialist) provision of health care for this group. We find that the development of increasingly 
integrated policy responses to homelessness in the twenty-first century require a re-conceptualisation of approaches to health care for homeless people, which can more explicitly address transitions from specialist intervention to more integrated mainstream provision.

\section{Homelessness and health: national frameworks in Norway and Scotland \\ Norway}

Along with Sweden and Denmark, Norway is known for its decentralised health care system (Byrkjeflot and Neby, 2004). Municipal health services in Norway are mainly financed through generic central state grants or allocations and municipal tax revenues. The municipalities may prioritise certain aspects of expenditure within the general framework of financial allocation. Other mechanisms employed by the State to regulate the municipalities include information and competence development, common performance indicators and reporting. In Norway it was previously a common assumption that there were few or no inequalities in health and living conditions in the period after World War II (Grøholt et al., 2007). However, throughout the 1980s and 1990s, Norway saw increased attention towards health inequalities and by the end of the 1990s also increased concern about the homelessness question (Ulfrstad, 1997; Dyb et al., 2004; Dyb, 2005). The historical commitment to universalism can be an explanation as to why the focus on homelessness came relatively late in Norway and there has also been less research on, and policy attention to, health and homelessness than in other countries (Ytrehus, 2002).

Within this context of increasing awareness of inequality, poverty and homelessness, at the beginning of the 20oos Norway established a single comprehensive national strategy to address homelessness, $P a ̊$ vei til egen bolig (A Path to a Permanent Home) (KRD, 2005; Husbanken, 2006). In this strategy, health care for homeless people in Norway was treated in a universalistic way which can be regarded as the integration of 'the homeless and health issue' into all areas and levels of policy-making (Sveri, 2007). The regulatory implication of the Norwegian strategy to reduce homelessness was that it should not be implemented by one service or a specific professional authority. Rather, according to the intention in the strategy, homelessness should be addressed in all relevant policy areas and the strategy is an inter-ministry strategy.

The overarching aims of the Norwegian homelessness strategy were that demands for eviction should be reduced by 50 per cent and that the number of evictions should be reduced by 30 per cent. Other aims were that no one should have to spend time in temporary accommodation after being released from jail or after discharge from an institution; no one should be offered overnight accommodation without a quality agreement; and no one should stay more 
than three months in temporary accommodation (KRD, 2006). The strategy has not emphasised 'hard' national regulations, but rather 'soft' governance by comparative evaluation of performance of the municipalities against common objectives, and policy suggestions and recommendations. There has also been an emphasis on funding networks and forums for communication and mutual learning, along with initiatives to help the strategy implementation process at the local level (KRD, 2006).

The homelessness strategy addressed any lack of access to health services due to structural issues by emphasising that a range of welfare services have responsibility for meeting the varied needs of homeless people. Consequently, the Norwegian homelessness strategy does not aim to develop separate new services, whether health services or other services for homeless people. This is in line with the basic principles of organisation in the Norwegian health services, which state that no special care services shall be established. There is, then, a clear goal within the strategy to combat and prevent homelessness - that no specific health service for homeless people is developed (KRD 2005, Husbanken 2006).

However, there has been some limited public care service provision for persons with substance dependence problems (who may also be homeless), reflecting increased awareness of health problems among this group (Kurtze and Eide, 2003; Ruud and Reas, 2003). Although the principle that the ordinary healthcare system shall include everyone (including those with substance dependence problems) has been restated (Helsetilsynet 2005), there have been discussions about how to enable the existing system to reach all persons in need of health care (Norwegian Ministry of Health and Care Services, 2008) and about whether some selective services designed to respond to weaknesses in universal provision are needed (Sundin, 2000, Westin, 2000).

The Norwegian homelessness strategy reflects the basic principle of municipal autonomy in service provision as it does not dictate centralised directives for implementation at the local level. In terms of governance, it leaves municipalities free to organise their services independently in order to meet the needs of homeless people in their localities. The strategy points out that the municipalities have a responsibility to provide services to all residents, including those who are homeless, but it does not make specific mention of health problems. The Norwegian strategy has not developed specific standards for municipalities to use to regulate and/or enforce access to healthcare for homeless people. Neither has it provided guidelines on which models should be used for service provision, although it does define goals for output.

The homelessness strategy leaves the responsibility for implementing appropriate measures to the municipalities. The freedom of municipalities in the choice of organisational model must be seen against the background of the strong independence which Norwegian municipalities have been given for their welfare and service production. Almost all resource allocation rules and decisions 
are made at the local/municipal level which is characterised by a high degree of autonomy from the central state.

A further scheme implemented under the auspices of the Norwegian homelessness strategy was a state grant that aimed to contribute to a long-term municipal focus on services to prevent homelessness. The grant period lasted from 2004 to 2007 (Ytrehus et al., 2007a). The purpose of the grant was to ensure long-term municipal commitment to offering services that meet the needs of homeless people independently of the main grant programme. According to the guidelines, this grant should be anchored in home care services or the social services, and it should contribute to cooperation between municipal departments and voluntary organisations working with homeless people. The grant should go directly to work with clients and be used for services delivered in the user's home. A great number of municipalities have availed themselves of this grant (Ytrehus et al., 2007a; Ytrehus et al., 2007b). Evaluations show that social services had primary responsibility for the grant and its use in the municipalities. Health services were less involved.

So, even though the national strategy has a mainstreaming approach to the issue of homelessness, some sectors are nevertheless more involved than others and this is especially true at the local level. Relatively few municipalities have chosen to use the homelessness grant to strengthen the health service. This is despite home care services being organised as ambulatory outreach services that should be available to all, irrespective of housing circumstances or other characteristics. Outreach work on substance abuse and mental health have long been recognised and acknowledged as closely related to homelessness and as important tools to reduce homelessness. An evaluation of the Norwegian effort to reduce homelessness has shown that the grant has led to some change in the already existing social services with more weight on outreach work, as well as part of the grant being used to establish new outreach services (Ytrehus et al., 2007a).

The dissemination of knowledge and the development of professional competence have also been given a central role in the Norwegian homelessness strategy, although competence development has not been specifically directed at health problems or the health sector (Sveri, 2007). The competence enhancing educational programmes established under the auspices of the strategy have been delivered by colleges of social studies. Homelessness is now addressed in other political and expert documents from national health authorities. For example, the Homelessness Strategy is mentioned in the White Paper 'On Housing Policy' (Norwegian Ministry of Local Government and Regional Development, 2004), the Plan of Action for Combating Poverty (Norwegian Ministry of Ministry of Social Affairs, 2003), which has been followed up in the Plan of Action to Combat Poverty (Norwegian Ministry of Labour and Social Inclusion, 2007), and the White Paper on 'A Tolerant, Secure and Creative Oslo Region' (Norwegian Ministry of Local Government and Regional Development, 2007). 
A clinical guideline on mental health care on the municipal level was published in 2006. The guideline had a comprehensive chapter on the housing situation for persons with mental disorders and on how to help them achieve a stable housing situation. In Norway, then, it seems likely that the national homelessness strategy has put the issue on the agenda across service sectors.

\section{Scotland}

In Scotland the National Health Service (NHS) remains a universal welfare service, publicly funded through taxation and available free of charge at the point of seeking or receiving treatment. Health services in Scotland are the responsibility of fourteen NHS Boards and the thirty-two local authorities (municipalities) do not have a direct role in the provision of health services. Health Boards generally cover geographical areas larger than local government municipalities, but the National Health Service Reform (Scotland) Act 2004 provided for the establishment of Community Health Partnerships (CHPs) matching local authority boundaries in order to co-ordinate effectively with local authority service provision (Scottish Executive Health Department, 2004). CHPs were expected to seek to reduce local health inequalities, acknowledging the varying needs of different groups, including homeless people, but their effectiveness was questioned in a national review which recommended a further fundamental review of partnership working between the health service and local authorities (Audit Scotland, 2011).

Scottish municipalities have strategic responsibility for housing, social work and social care services, and all but six retain a municipal (council) housing stock. Since 1977, Scottish local authorities have had legal duties to assist households assessed as 'homeless and in priority need', mainly by offering them secure housing in the social rented sector. Most families with children, retired people and those with severe health problems or impairments fell within the priority need category, while most single people were excluded as 'non-priority' unless they were recognised as vulnerable in some way. Following devolution in 1999, the Labour/Liberal Democrat coalition recognised the need for a broad review of homelessness and set up the Homelessness Task Force (2000, 2002), whose final report Helping Homeless People: An Action Plan for Prevention and Effective Response (2002) effectively became the national policy framework.

The Homelessness Task Force review was followed by legislative change, compared to the 'softer' policy approach in Norway, and this is one of the most significant differences in approach between the two countries. First, the Housing (Scotland) Act 2001 required local authorities to assess the level of homelessness in their areas and to develop local homelessness strategies. The 2001 Act also extended the duty to provide temporary accommodation to all homeless households until a decision was made on their application. Next, the Homelessness etc. (Scotland) Act 2003 substantially widened the 
legal safety net for homeless people by announcing the abolition of the distinction between 'priority' and 'non-priority' need groups over a tenyear period. This very ambitious target meant that by 2012, local housing authorities would have a duty to assist virtually all homeless households to obtain settled accommodation (unless they were found to be intentionally homeless). Although the Homelessness Task Force (2002) made fifty-nine wide-ranging recommendations to improve services to homeless people in Scotland, the '2012' target has been the goal which has been most closely monitored and the post2000 Scottish and Norwegian homelessness frameworks have been acclaimed internationally as coming very close to implementing a right to housing for all (Anderson, 2009).

The post-2007 Scottish National Party (SNP) government maintained the commitment to delivering this programme, with two key policy shifts: greater encouragement of use of the private rented sector and the adoption of a housing options approach to homelessness prevention (Scottish Government, 2009). Homelessness prevention was defined as 'the most effective, appropriate and sustainable housing outcome for the person concerned', following a person centred assessment (Scottish Government, 2009: 4). In 2010, funding was announced to support the development of five 'housing options hubs' across Scotland, where local authorities now work together in regional groupings to share practice on best meeting the needs of housing/homelessness applicants with a view to preventing homelessness where possible (without diminishing their duties under the 2012 safety net).

Since 2008/9 performance reporting for Scottish local authorities has been through Single Outcome Agreements (Scottish Government, 2007a). Authorities agreed to deliver on a specified set of commitments from within the funding package provided. In the same period, ring-fenced government funding for implementation of homelessness initiatives was transferred into the overall local government settlement with discretion to each authority as to how to allocate funding. This could of course result in reduced priority for homelessness compared to other local authority responsibilities. However, by 2011, Scottish homelessness statistics indicated local authorities were 88 per cent of the way towards meeting the 2012 target of abolishing the priority/non-priority need distinction, although there was variation in performance across individual municipalities (Scottish Government, 2011).

Notwithstanding the significance of the wider homelessness reforms in Scotland, the focus in this paper is on how the health care needs of homeless people are met within that framework.

The Homelessness Task Force (2002) report acknowledged the need for health and other services to contribute to effective solutions to homelessness. The prevalence of homelessness in Scotland reflects the wide legal definition which resulted in more than 55,00o homelessness applications (just over 1 per 
cent of the total population) in 2010/11, some 63 per cent of which were single person households, predominantly single males (Scottish Government, 2011). Some 36,440 were assessed as homeless and in priority need, and 14,000 of these reported at least one kind of support need (often health related), with a health/health-related issue the reason for being considered in priority need in more than a fifth of cases.

Although NHS services should be equally available to homeless people as the general population, the health care needs of homeless people were not always fully met by mainstream health services (Homelessness Task Force, 2002). Such exclusion is most likely to affect either those who are not accepted as homeless and in priority need (or who perhaps do not even present for assistance), as well as those who spend particularly long periods of time in temporary accommodation, or moving around between insecure accommodation. From 2001, NHS boards were required to produce health and homelessness action plans for service improvement, based on an assessment of local need and accessibility of services. The health needs of homeless people were also recognised as part of the broad goal of reducing health inequalities (Health Scotland, 2004). In 2005, the Scottish Executive introduced Health and Homelessness Standards for NHS boards, with delivery through local CHPs (Scottish Executive, 2005). Thus, meeting the health care needs of Scottish homeless people has been addressed through policy guidance, but not so far through legislative change (as was the case for their housing needs).

While the Scottish homelessness framework sought to be universal in the same sense as the Norwegian strategy, it had to take account of both evidence of exclusion of some homeless people from mainstream health services, and existing provision of some specialist services to meet their health care needs. For example, some NHS Boards in Scotland have financed services provided mainly or specifically for homeless people, most notably in the cities of Edinburgh and Glasgow where there were more substantial populations of homeless people whose health care needs were not being fully met by the regular NHS services.

As with the wider homelessness framework, the post-2007 SNP government has retained the commitment to the Health and Homelessness Standards, but to date there has been no clear framework for monitoring their implementation or any published evaluation of their impact. None of the broad targets in the Scottish Government's 2007 health action plan related specifically to housing or homelessness, but 2009 homelessness prevention guidance noted that Health Boards should have well-developed local liaison with relevant homelessness services, including discharge protocols, information sharing and effective joint working arrangements (Scottish Government, 2007b, 2009). Such arrangements would build on existing plans and the Health and Homelessness Standards. Specifically, the homelessness prevention guidance stated that those homeless 
on admission to hospital should never be discharged without referral to appropriate services in the community (Scottish Government, 2009:30), and local arrangements should be in place for working with housing, addiction and mental health services. Multi-agency collaboration to improve access to health care for homeless people in Scotland was largely directed from the 'top' of government, in contrast to the high degree of local autonomy in Norway. However, the Health And Homelessness Standards emerged from the work of a steering group with considerable 'bottom-up' input from a wide range of stakeholders, including homelessness campaign organisations.

As in Norway, the Homelessness Task Force (2002) review recommended that all relevant workers should receive appropriate training. For example, it was specifically suggested that training programmes for drug and alcohol workers should include an understanding of issues relating to homelessness. Although these recommendations did not translate directly into professional competence programmes, vocational qualifications exist in social care and housing support, as well as in the professions of social work, nursing and housing management. In this respect, the Scottish framework is, like the Norwegian strategy, 'multiministry' or cross-departmental. However, the fact that local authorities remain the lead agencies in tackling homelessness in Scotland is perhaps a key difference in practice, such that the Scottish framework is rather more directly 'housing-led' than its Norwegian counterpart.

\section{Meeting the health needs of homeless people: evidence and change}

The health care needs of homeless people and their access to health services have been a focus for a large number of research studies as well as for occasional national and international reviews of the evidence base (Pleace and Quilgars, 2004; Wright and Tomkins, 2005). More acute forms of homelessness such as prolonged periods of rooflessness are likely to impact more substantially on individuals' health than, say, shorter stays in temporary accommodation. That said, poor housing can in itself be a cause of health problems and difficult housing conditions can make it problematic to handle existing chronic illnesses (including both mental and physical health problems). Arguably, in the post2000 period, issues of health and homelessness had become the most severe dimension of housing-related health issues (Anderson and Barclay, 2003). Living conditions can make treatment regimes and treatment plans hard to handle, because of difficulties with controlling diets, getting necessary rest and following medication regimes. Despite recognition of the health problems of homeless people however, international research reviews have concluded that there remains a lack of rigorous evaluation of the effectiveness of housing interventions in improving their health outcomes (Pleace and Quilgars, 2004; NICE, 2005). 
It is the recognition of homeless people's exclusion from health services and inadequacy of treatment which has resulted in the development of specialist (selective) services in many countries. For example, health centres which cater mainly/exclusively for homeless people have aimed to counter some of the weaknesses in mainstream (universal) provision (Anderson et al., 2006; FEANTSA, ${ }^{1}$ 2006). In an international review, Pleace and Quilgars (2004) identified a range of such specialist services including: informal adaptations to mainstream services; specialist primary care services and specialist complementary services (e.g. alcohol and drug support, dentistry, podiatry, opticians). Specialist services were generally more comprehensive in urban areas with higher concentrations of homelessness. However, Pleace and Quilgars (2004) found no evaluations of informal adaptations to mainstream services, such as GPs allowing registration with a temporary address or of the practice of doctors visiting hostels. Their review concluded that primary care services were increasingly integrated with other services aimed at jointly preventing homelessness and resettling homeless people. It appeared that flexible working could achieve high patient satisfaction and joint working was recommended, though had not been evaluated for clinical effectiveness.

In Lester's (2003) study in England, difficulties encountered by homeless people in the health service included: a lack of flexibility (e.g. with appointment systems); lack of fit between the needs of homeless households and meeting prescribed targets; lack of effective joint working between mainstream health practice and housing and care/support providers; and negative attitudes of staff and other patients towards homeless people. Proponents of specialist services argued that they helped overcome some of these barriers and that homeless people often found such services more welcoming. In contrast, integrated/mainstream service provision had the advantages of offering the full range of ordinary health services in a non-segregated environment. Lester recommended a 'seamless service provision between specialised and mainstream primary care services' (2003: 60): although specialist services may be required while homeless people were in crisis, there should be an expectation of moving to mainstream provision once people were reasonably settled. Transitional services were therefore needed to provide a bridge between segregation and integration. However, evidence at the time suggested that specialist health projects were good at providing care, but less good at achieving reintegration (Lester, 2003) and very little empirical research appears to have emerged to contradict this in the subsequent period (e.g. see the reviews by Anderson et al., 2006 and FEANTSA, 2006).

The same themes seem to recur in the most recently available evidence. Joly et al.'s (2011) study in an English city suggests that interagency working to support the health of homeless people reflects concerns of the wider population (for example around prevalence of tuberculosis or high risk street behaviour) rather than how to best meet the needs of vulnerable adults in temporary 
accommodation. This particular study did not address the issue of interagency working to reintegrate those who experience homelessness into mainstream housing and health care. In the context of Denmark and the Scandinavian model of universal health care, Thiesen (2011) argues that vulnerable people's use of health care can indicate faults in the health service which affect the whole population and that the focus needs to be on barriers to accessing the care to which they are entitled. Thiesen's data from Copenhagen show that homeless people still experience a higher degree of all types of diseases than the general population and than other disadvantaged groups. Further, a very low percentage of homeless clients in this study had a regular relationship with a general practitioner. Thiesen argues that even where treatment is given, co-ordination and completion of treatment is lacking, and that the focus is very much on emergency treatment rather than long-term health care. Thiesen concludes that lessons for mainstream service provision could be learned from the flexibility of specialist provision.

To an extent, we can see the contrasting impact of these issues on policy development in Scotland and Norway. In Scotland, where, for example, health services have been provided in specialist clinics for homeless people or direct to temporary accommodation, those moving out of homelessness face the challenge of achieving 're-integration' into mainstream health care, as well as getting used to living independently in the community again. In contrast, in Norway, since almost no separate services have been developed, the challenge will be identifying any vulnerable or homeless people who do fall through even this strong safety net and ensuring their health care needs are met. FEANTSA (2006: 18) identified 'special healthcare centres and initiatives that had come into being in an effort to reach people who were homeless and not in any kind of regular contact with the general healthcare system' across the European Union. This would suggest that Norway has been very much the exception rather than the rule in not having specialist health service provision for homeless people.

The FEANTSA report (2006: 21) concluded that having all of one's health needs met through emergency or specialist services would not constitute quality health care, irrespective of the quality of such services. Specialist structures were considered problematic as the creation of such services indicated acceptance of the fact that mainstream health care provision would remain inaccessible to people experiencing homelessness. Another argument against the development of specialist services for homeless people is that there are significant differences in the health care needs of different groups of homeless people - for example homeless families may have very different needs to those of young single people. A universal health care system should always design health services to address the needs of various groups, while a selective service would not be able to meet the wide range of needs across all groups who experience homelessness. That said, while ideally all needs should be met through mainstream care, specialist 
TABLE 1. Outline of models of health services to homeless people in Scotland and Norway

\begin{tabular}{lcc}
\hline & Mainstreaming & Segregated \\
\hline $\begin{array}{l}\text { Centralised } \\
\begin{array}{l}\text { Strongly directed by Central } \\
\text { Government) }\end{array}\end{array}$ & $\begin{array}{c}\text { Scotland (aim and some } \\
\text { practice) }\end{array}$ & $\begin{array}{c}\text { Scotland (necessary to counter } \\
\text { exclusion) }\end{array}$ \\
$\begin{array}{l}\text { Decentralised } \\
\text { (Strong autonomy for Local } \\
\text { Government) }\end{array}$ & $\begin{array}{c}\text { Norway (aim and } \\
\text { practice) }\end{array}$ & $\begin{array}{c}\text { Norway (resistant, minimal } \\
\text { exclusion) }\end{array}$ \\
\hline
\end{tabular}

services could help in the process by, for example, being tailored to work with people experiencing crisis. In this sense it is important to think about a process of responding to unmet needs with the aim of optimising the use of mainstream health service by all groups in society, including those who experience homelessness.

Although Norway has not seen the development of specialist provision, there remains a need to establish whether some people experiencing homelessness also experience exclusion from and inadequacy of health care, even if to a lesser extent than in other countries. It is reasonable to assume that the national homelessness strategy has resulted in increased attention to the role and tasks of health services in connection with discharges from institutions. However, studies have indicated that the question of housing and the risk of homelessness remain topics which are still scantly treated by healthcare institutions. For example, Taksdal et al. (2006) found that addiction agencies and mental health agencies did not pay sufficient attention to, or plan for, ensuring a stable housing situation at discharge. The principle of equality of access to health care has been re-established in Scotland in the twenty-first century, but there remains a lack of evidence about the effectiveness of what are generally considered to be progressive policies. There is limited robust evidence as to how well co-ordination of services is working and, indeed, about to how effectiveness should even be measured. So, the question for future research appears to be 'how are outcomes changing with respect to the health of homeless people in the Scotland?' Policies have been directed at the problem but their impact is not yet clear.

Central government has taken a strong lead on co-ordinated policy development for Scotland and the challenge is for local agencies to deliver on implementation and for central authorities to ensure effectiveness is robustly monitored. In comparison, Norwegian municipalities have much greater autonomy in terms of the delivery of health care services and research might usefully examine whether this means that homeless people in some localities are better or less well served than in others. Table 1 summarises the key differences between the Scottish and Norwegian strategies to meet the health care needs of 
homeless people. It could be argued that in Scotland the overarching neoliberal welfare model creates more social exclusion (including homelessness) than Norway, and therefore necessitates more complex interventions. It must be remembered, however, that even in Scotland a high proportion of those who experience homelessness may well be able to access health care services on exactly the same basis as their better housed counterparts. Specialist services develop to meet the specific needs of more excluded groups, for example those whose homelessness is combined with other health and social issues resulting in a more acute or prolonged experience of homelessness.

Our analysis suggests that with respect to health and homelessness, it is essential to acknowledge complexity within the characterisations of liberal and universal welfare states. In the case of Scotland, the process of devolution has been very significant in providing a buffer against the application of more radically neoliberal health and housing policies. Scotland retains a proportionately greater social housing stock, a stronger homelessness legal safety net and a more universal health care system than England. While Norway retains many characteristics of the universal welfare state, its model was never characterised by the development of social rented housing and this may constrain Norway's policy responses to a homelessness crisis (which only emerged in the very late phase of welfare state evolution). Similarly, the emerging development of specialist services presents a challenge to the universal health care model.

While the framework in Table 1 above could be extended to other countries and welfare systems, it is also important that such analysis takes account of changes over time and the impact of policy change. In Scotland, the post-2000 period has sought to achieve integration, at least in terms of policy and strategy, with evaluation of practice still required. There also remain questions about how, precisely, mainstream and specialist health care provision are defined. Would this depend on service availability to all potential clients, the location at which health care is delivered (i.e. the same as for the housed population, or different?), funding source - or some combination of these? For example does the provision of, say, a visiting (mainstream) GP service in a hostel for homeless people constitute 'mainstream' service provision? In the case of Norway, the central question in relation to the national strategy has been the implementation process on the local level. To what extent have different measures encouraged Norwegian municipalities to prioritise homelessness prevention? Several evaluation reports have identified a greater emphasis on and understanding of the needs of homeless people and various financial support measures and other initiatives have had a positive influence on how the local agencies prioritise housing and help to homeless people (Ytrehus et al., 2008). Nevertheless, the question arises as to whether this awareness and priority will continue without additional support from the central government and levels of both awareness and help provided still vary widely among Norwegian municipalities. 


\section{Conclusion: towards integrated approaches to meeting the health needs of homeless people}

The causes of homelessness are numerous and complex, reflecting economic, social and health circumstances as well as the interplay between these factors and the housing system in any country (see, for example, Anderson and Christian, 2003; Busch-Geertsema et al., 2010). Homelessness cannot be exclusively linked to particular social characteristics or health problems. Where there is an aspiration of access to mainstream health care for all, does the continued provision of specialist services for homeless people imply an ongoing dilemma for such welfare states? Or in some ways may the two approaches be better understood as different means to the same end? To an extent this would depend on whether homeless people can be seen as a distinct minority group in any society, at least for a period of time. In such circumstances, one critique of universal service provision would be that it had failed to meet the needs of this particular group. It could therefore perhaps be argued that to resolve both their homelessness and their health problems, the group should be provided with specialist services which address their distinct needs. However, we would argue that homelessness is not best interpreted as something experienced by a discrete group, easily separable from the rest of society. Rather, people who experience a period of homelessness are an inseparable part of society, in the same way as those who are vulnerable or disadvantaged in other ways. While there may be some factors closely associated with the risk of experiencing homelessness, it is still not possible to identify exactly who will become homeless. This complex causality suggests that mainstreaming (or universal provision) should indeed be the preferred way for society to meet the health care needs of homeless people.

This initial comparison of health and homelessness in Norway and Scotland leaves considerable scope for further research, notably empirical evaluation of the outcomes of policy change. Methods for comparison would need to take account of the distinct structures for the health care delivery at national and municipal levels. Such a study might identify how the real world of access to health care for homeless people is evolving in terms of the debate about mainstream versus specialist provision. Is the Norwegian universal welfare state still effective in meeting the health care needs of very vulnerable groups such as those who are homeless? Can a transition be identified in Scotland where the 'necessary evil' of specialist provision to counter the exclusion associated with a liberal welfare regime is declining, as better integration of services is achieved? And what lessons can be learned for other nations and welfare regimes seeking to develop more effective, integrated responses to the problem of homelessness? Is there a 'middle-way' between the centralised Scottish system and the highly decentralised Norwegian system, which can fully value informal co-operation and 'bottom-up structures', as well as strong central government leads? 
Across European countries, a new consensus may be emerging that specialist services should only be required by those in the most severe circumstances with complex health conditions and related lifestyle issues, and only for a limited period. The goal, however, should remain settled accommodation and equal access to mainstream health services. The need for joint working across housing and health agencies is more or less universally accepted (Busch-Geertsema et al., 2010), although access to one service should not be dependent on any other. The period 2000-2010 saw very significant developments in terms of the introduction of national homelessness strategies across Europe, but there remained a lack of evidence on the effectiveness of policy change. Outcomes of evaluations at the beginning of the subsequent decade may well be affected by the prolonged financial crisis affecting much of Europe and which threatens to undermine the achievements of previous policy initiatives (Norway would be less affected than Scotland in this respect).

Following a decade of significant progress in the development of national homelessness strategies across and beyond Europe, does the question of 'mainstream versus specialist provision' remain an ongoing dilemma or a practical means to the same end? It seems that the fundamental question has changed and can be reconceptualised as how to support a process of integration (or reintegration) rather than a choice between conflicting strategies. An emerging consensus is identifiable: that specialist health care provision for vulnerable groups such as homeless people should be transitional and ultimately designed to aid integration into mainstream services. The new question is how that transition is to be achieved, and to what extent countries are achieving that goal? In this respect, Scotland may offer a model for evaluation of transitional services while Norway may remain a benchmark for universal inclusive provision.

\section{Acknowledgements}

We are grateful to the Norwegian Housing Bank (Husbanken) for funding the research on which this article is based. We are also grateful to colleagues in the Welfare Policy, Homelessness and Social Exclusion Working Group of the European Network for Housing Research, in the Nordic Network for Homelessness Research, in our own institutions and our anonymous referees for helpful comments throughout the process of revising this article.

\section{Note}

1 FEANTSA is the Fédération Européene des Associations Nationales Travaillant avec les SansAbris or European Federation of National Organisations Working with the Homeless. It is an EU-wide umbrella organisation for the homelessness not-for-profit sector and carries out research and campaign activities contributing to the fight against homelessness in Europe. http://www.feantsa.org/code/en/hp.asp

\section{References}

Alcock, P., Glennerster, H., Oakley, A. and Sinfield, A. (2001), Welfare and Wellbeing: Richard Titmuss's Contribution to Social Policy, Bristol: Policy Press. 
Anderson, I. (2009), 'Homelessness policy in Scotland: a complete safety net by 2012?', in S. Fitzpatrick, D. Quilgars and N. Pleace (eds.), Homelessness in the UK: Problems and Solutions, Coventry: Chartered Institute of Housing, pp. 107-24.

Anderson, I., Baptista, I., Wolf, J., Edgar, B., Benjaminsen, L., Sapounakis, A. and Schoibl, H. (2006), The Changing Role of Service Provision: Barriers of Access to Health Services for Homeless People, Brussels: FEANTSA.

Anderson, I. and Barclay, A. (2003), Housing and Health, in A. Watterson (ed.), Public Health in Practice, Basingstoke: Palgrave, Chapter 7.

Anderson, I. and Christian, J. (2003), 'Causes of homelessness in the UK: a dynamic analysis', Journal of Community and Applied Social Psychology, 13: 105-18.

Audit Scotland (2011), Review of Community Health Partnerships, Edinburgh: Audit Scotland.

Busch-Geertsema, V., Edgar, D., O'Sullivan, E. and Pleace, N. (2010), 'Homelessness and homeless policies in Europe: lessons from research', Report for European Union Consensus Conference on Homelessness, FEANTSA, Brussels.

Byrkjeflot, H. and Neby, S. (2004), The Decentralized Path Challenged? Nordic Health Care Reforms in Comparison, Working paper 2-2004, Bergen, Rokkansenteret.

Department of Health (2011), Health and Social Care Bill, London: Department of Health.

Dyb, E., Solheim, L. and Ytrehus, S. (2004), Sosialt perspektiv på bolig, Oslo: Abstrakt forlag.

Dyb, E. (2005), Prosjekt bostedsløse - Evaluering av et fireårig nasjonalt prosjekt, Byggforsk skriftserie 7-2006.

Esping-Andersen, G. (1990), The Three Worlds of Welfare Capitalism, Cambridge: Polity Press.

FEANTSA (2006), The Right to Health is a Human Right: Ensuring Access for People who are Homeless, Brussels: FEANTSA.

Grøholt, E. K., Dahl, E. and Elstad, J. I. (2007), 'Health inequalities and the welfare state', Norsk epidemologi, 17: 1, 3-8.

Helsetilsynet (2005), Rusmiddelmisbrukernes helseproblemer og helsetjenestetilbud i et overordnet tilsynsperspektiv, Rapport fra helsetilsynet $2 / 2005$.

Health Scotland (2004), Delivering Health Care to Homeless People: An Effectiveness Review (Research in Brief, 13), Edinburgh: NHS Health Scotland.

Homelessness Task Force (2000), Helping Homeless People: Legislative Proposals on Homelessness, Edinburgh: Scottish Executive.

Homelessness Task Force (2002), Helping Homeless People: An Action Plan for Prevention and Effective Response, Edinburgh: Scottish Executive.

Husbanken (2006), På vei til egen bolig: Statusrapport 1/2006 (The pathway to a permanent home: report on the situation 1/2006), Oslo.

Joly, L., Goodman, C., Froggat, K. and Drennan, V. (2011), 'Interagency working to support the health of people who are homeless', Social Policy and Society, 10: 4, 523-36.

Kemeny, J. (2001), 'Comparative housing and welfare: theorising the Relationship', Journal of Housing and the Built Environment, 16: 53-70.

Kurtze, N. and Eide, A. (2003), Helsetilstand hos tunge rusmiddelbrukere, SINTEF Unimed, STF78 A035002.

KRD (2006), På vei til egen bolig - En strategi for å forebygge og bekjempe bostedsløshet: tilskudd,eksempler, samarbeid og deltakelse (The pathway to a permanent home - a strategy to prevent and combat homelessness: subsidies, examples, collaboration and participants), Oslo.

Lester, H. (2003), 'Homelessness and health: the role of primary care', in G. Paramjit and G. de Wildt (eds.), Housing and Health: The Role of Primary Care, Abingdon: Radcliffe Medical Press, pp. 47-65.

NICE (2005), Housing and Public Health: A Review of Reviews of Interventions for Improving Health, NHS: National Institute for Health and Clinical Excellence (NICE).

Norwegian Ministry of Labour and Social Inclusion (2007), Plan of Action to Combat Poverty, Attachment to the Propositon to the Storting No. 1 (2006-2007).

Norwegian Ministry of Local Government and Regional Development (2004), On Housing Policy, Report No. 23 to the Storting (2003-2004). 
Norwegian Ministry of Local Government and Regional Development (2007), White Paper on 'A Tolerant, Secure and Creative Oslo Region', Report No. 31 to the Storting (2006-2007).

Norwegian Ministry of Health and Care Services (2008), Norwegian National Action Plan on Alcohol and Drugs (2008-2010), Oslo.

Norwegian Ministry of Ministry of Social Affairs (2003), Plan of Action for Combating Poverty, Report No. 6 to the Storting (2002-2003).

Pleace, N. and Quilgars, D. (2004), Delivering Health Care to Homeless People: An Effectiveness Review, Edinburgh: Health Scotland.

Ruud, T. and Reas, D. (2003), Helsetjenester for tunge rusmiddelbrukere, SINTEF Unimed, STF78 A035003.

Scottish Executive Health Department (2004), Community Health Partnerships: Statutory Guidance, Edinburgh: Scottish Executive.

Scottish Executive (2005), Health and Homelessness Standards, Edinburgh: Scottish Executive.

Scottish Government (2007a), Better Health, Better Care: Action Plan, Edinburgh: Scottish Government.

Scottish Government (2007b), Concordat between the Scottish Government and Local Government, Edinburgh: Scottish Government.

Scottish Government (2009), Prevention of Homelessness Guidance, Edinburgh: Scottish Government and COSLA.

Scottish Government (2011), Operation of the Homeless Persons Legislation in Scotland: 201011, Edinburgh: Scottish Government, http://www.scotland.gov.uk/Publications/2011/o8/ $30083716 / 0$.

Sundin, G. (2000), 'Stoffmisbrukere må ha en særomsorg', Tidsskr Norske Loegeforen, 120: 3596.

Sveri, G. (2007), Curbing Homelessness in Norway, Oslo: Husbanken.

Thiesen, H. (2011), 'Access for homeless people to healthcare in Northern Europe: the Danish/Scandinavian perspective', Homeless in Europe, Brussels: FEANTSA, pp. 7-10.

Titmuss, R. (1968), Commitment to Welfare, London: Allen \& Unwin.

Taksdal, A., Breivik, J. K., Ludvigsen, K. and Ravenberg, B. (2006), På randen av å bo: Erfart kunnskap om livet og flyttingen mellompsykiatri, rusomsorg, gater, hospitser og egne boliger, Bergen: Rokkansenteret.

Ulfrstad, L. M. (1997), Bostedsløshet $i$ Norge: Kartlegging av bostedsløse $i$ kontaktmed hjelpeapparatet, Prosjektrapport 216, Norges Byggforskningsinstitutt.

Westin, S. (2000), 'Tid for å gjenetablere særomsorgen?', Tidsskrift Norske Læegeforen 2000, 120: 1613.

Wright, N. and Tomkins, C. (2005), How Can Health Care Systems Effectively Deal with the Major Health Care Needs of Homeless People? Health Evidence Network, Copenhagen: World Health Organisation Regional Office for Europe.

Ytrehus, S. (2002), 'Det boligsosiale feltet-ansvar og kompetanse', Tidskrift for Velferdsforskning, 5:3.

Ytrehus, S., Sandlie, H. C. and Skårberg, A. (2007a), Fra bostedsløs til egen bolig: Delevaluering av tilskuddet til oppfølgingstjenester, Fafo-rapprot 23, Oslo: Fafo.

Ytrehus, S., Hansen, I. L., Langsether, Å., Sandlie, H. C. and Skårberg, A. (2007b), Tjenester til bostedløse i ti kommuner, Fafo-rapport 23, Oslo: Fafo.

Ytrehus, S., Sandlie, H. C. and Skog Hansen, I. L. (2008), På rett vei: evaluering av prosjekt bostedsløse to år etter, Fafo-rapport, Oslo: Fafo. 